\title{
A COMPARATIVE STUDY OF SENTENCE SYSTEM BETWEEN SHERPA AND TAMANG LANGUAGE
}

\author{
Dawa Sherpa Ph.D. \\ Lecturer, Tribhuwan University, Mahendra Ratna Campus, Tahachal, Department of Education Nepali
}

Article DOI: https://doi.org/10.36713/epra6319

\begin{abstract}
Sherpa language is spoken by Sherpas and Tamang language is spoken by Tamangs. Both of these languages fall under Tibeto-Burman language family. The present comparative study between these two languages is qualitative in nature. Data collection for the study was made with purposive interview and conclusion has been drawn. Both language bear resemblance in the sentence structure as subject + object + verb pattern. Both the languages have similarity in sentences meaning as declarative, interrogative, optative, imperative, subjunctive, indicative and exclamatory sentences from the formal point of view. Both the languages have similar simple, compound and complex sentences. These languages differ from Nepali language in grammatical structure. Both the languages do not have sentence congruity in the structure. They seem a grammatical on the basis of number and gender.
\end{abstract}

KEY WORDS: A grammatical, sambhota, Target language, phonological linguistic competence/ linguistic power.

\section{INTRODUCTION}

Both Sherpa language and Tamang language fall on Tibeto-Burman language family. They are written in Sambhota script. Sherpa language is spoken by Sherpas and Tamang language is spoken by Tamangs. According to the census 2011 report there are 1,14,830 Sherpa language speaker in Northen Himalayan regions of Nepal. Tamangs mostly live in the periphery of Kathmandu valley and scatter all over the country. Tamang speaking population is 5.11 percent of the total population on the basis of census report 2011. (2011:284). Tamang language is spoken by the largest number of population from the Tibeto-Burman language family in Nepal.

The Study aims at comparing the sentences of Sherpa language and Tamang language to the Nepali language. Both Sherpa language and Tamang language differ in sentence structure from Nepali language. In acquiring the target language the learner most produce the target language accurately in a continuous way. For this target language learning is possible through productive practice (Chaudron, 2007: 91). Therefore, both Sherpa language and Tamang language speakers learning Nepali language as target language should focus on constant practice and productive learning.

\section{STATEMENT OF THE PROBLEM}

The statement of the problem of this study is to find out the difference between sentence structure of Sherpa language and Tamang language and to compare the difference with Nepali language.

\section{OBJECTIVES}

The main objective of the study is to compare the sentence system of Sherpa language and Tamang language with Nepali language and to tabulate it.

\section{METHODOLOGY OF THE STUDY}

The comparative study between Sherpa language and Tamang language sentence system is qualitative in nature. The study is based on purposive study for selecting Sherpa language speakers and Tamang language 
speaker (Creswells, 2015: 207). The data collection has been made with the help of $\mathrm{MP}^{3}$ sound recording device adopting regional study, survey, observation and interview. Four Sherpa language speaker from Sekhimba and four Tamang language speakers from Katake village of Menchhyayam rural Municipalty ward no. 3 of Terhathum district have been the informant in this study (Das, 2013: 140). For this study use of applied linguistics for oral interview has been utilized to obtain data on target language acquisition (Nunan, 2010: 149).

There is no similarity between the phonological structure and system of two language (Crystal, 2003: 341). Comparison between two languages on phonological structure and system is easier but comparison of grammatical system is more difficult because grammatical structure in two languages is different and complex (Hocket, 2006: 261).

\section{Primary Source}

Data collection for the study was made by oral interview and questionnaire from 4 Sherpa language speakers of Sekhimba and 4 Tamang language speakers of Katake village of Menchhyayem rural municipality, ward no. 3 of Terhathum district (2016: 316). The informants have been selected with purposive sampling. Data collection has been made by interview, questionnaire and discussion.

\section{Secondary Source}

Published and unpublished dissertation, articles and dictionaries on Sherpa language and Tamang language have been used to collect linguistic data as secondary sources. Secondary sources have been used for the verification of primary sources. Conclusion of the study has been drawn by analysis and interpretation of the collected data in a comparative study.

\section{Pre-test}

The data has been used in this study with the pretest from the Sherpa language speaker and Tamang language speaker of Menchhyayem rural municipality, ward no. 3. Linguistic competence and language for competence on the speaker is directed by proficiency (Lyons, 1981: 165).

\section{Sentence System}

Usually, the words used in sentences are called phrase. The word without its derivation is called 'lexeme' (Pokhrel, 2054: 126). Sentence is such a linguistic construction that has one subject and a finite verb (Adhimari, 2068: 268). It is larger than a phrase. A Sentence expresses a concept. The grammatical unit larger than a clause is a sentence (Sharma, 2071: 291). The study of the sentences in Sherpa language and Tamang language has been made on the basis of this definition. Both the languages have the same type of sentence structure as subject + object + verb. Syntax studies the structure of sentences. The smallest unit in the structure of sentence is word. Phrases and clauses can also be used on constituents of sentence structure (Sherpa, 2077: 145). This study has been made to classify the sentence structure and meaning of Sherpa language and Tamang language on the basis of the above definition.

\section{Types of Sentences on the basis of Meaning}

The meaning given by the sentence is called sentence meaning. Sentence meaning is understand if only the user uses the sentence (Avasthi and Sharma, 2055: 201). In Tagmamic grammar sentence is the grammatical sequence. On these basis sentence is a complete structure which is independent (Bandhu, 2064: 90). On the basis of meaning sentences can be classified into six categories and structurally three types of sentences as simple, compound and complex on the basis of structures (Adhikari, 2071: 229-230). The sentences of Sherpa language and Tamang language have been compared on the basis of meaning.

\section{Assertive Sentence}

Assertive sentences assert the simple meaning of the sentence. the Simple intention of the speaker is expressed in assertive sentence (Awasthi and Sharma, 2055: 201). Every sentence has a finite verb. For example, the boy dances. He ate an orange. Both of these constructions are sentences (Adhikari, 2071, 203).

On the basis of this definition the assertive sentences of Sherpa language and Tamang language have been show in the table.

\begin{tabular}{|c|c|c|c|}
\hline Sherpa language & Tamang language & Nepali language & English language \\
\hline [neki sama soi] & [nai ka:n tsa:zi] & [maile vat k $\left.{ }^{\mathrm{h}} \mathrm{aĕ}\right]$ & I ate rice. \\
\hline [pasang khanba ga:l] & [pasang dim nizi] & [pasnag ghar gajə:] & Pasang went home. \\
\hline [mesi kegesung] & [mui hja:mu:la] & [vaisi karajo:] & The buffalo mooed. \\
\hline [thapemki tsja khunga:l] & [tja:nsinle na:sa bo:zi] & [tsille ku:k $\mathrm{k}^{\mathrm{h}} \mathrm{ra}$ lagj’] & $\begin{array}{l}\text { The eagle took the } \\
\text { chick. }\end{array}$ \\
\hline
\end{tabular}

The above assertive sentences have verbs [SoI), [ga:l], [kegesung] and [Khu:jga:1] in Sherpa language, [tsa:zi], [nizi], [hja:mu:la] and [bo:zi] in Tamang language [khaĕ], [gajo], [karajo] and [lagjo] in Nepali language respectively to refer to English verbs ate, went, mooed and took.

\section{Interrogative Sentences}

Only the interrogative pronoun differ in interrogative sentence from assertive sentence in Sherpa language and Tamang language. Question type declarative sentence is called interrogative sentence (Sharma, 
2071: 413). Unlike assertive sentences interrogative sentences end with rising intonation. The rise is denoted by question mark (?).

\begin{tabular}{|c|c|c|c|}
\hline Sherpa language & Tamang language & Nepali language & English language \\
\hline [su: sisung ?] & [k $\mathrm{k}^{\mathrm{h}} \mathrm{a}:$ la sizi ?] & [kว: marjə:] & Who died? \\
\hline [Kang kiru: ?] & [tik laba: ?] & [ke garne?] & What to do? \\
\hline [t's: lja:mu: ?] & [dha:te zja:ba: ?] & [kati ra:mro ?] & How beautiful? \\
\hline [kani diju: ?] & [khairi niba: ?] & [kahă: Ja:ne ?] & Where to go? \\
\hline [kang tibu:za ?] & [tik biba?] & [ke lek ${ }^{\mathrm{h}}$ ekJ: ?] & What did you write? \\
\hline [puzjung t $\mathrm{t}^{\mathrm{S}} \mathrm{ki}$ hwa:e ?] & [za: ghatleba: mu:la ?] & [t $\mathrm{t}^{\mathrm{S}}$ oro katro: ts ${ }^{\mathrm{h}} \mathrm{a}$ ?] & How old is your son? \\
\hline [papa: phepsung?] & [a:ba: phebrabazi ?] & [bu:ba: aunu:vajo: ?] & Did father come? \\
\hline [sama: ts ${ }^{\mathrm{h}} \mathrm{j}$ :sung ?] & [sJ:1 ts ${ }^{\text {hj }}$ Jizi ?] & 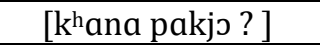 & Was the food cooked? \\
\hline
\end{tabular}

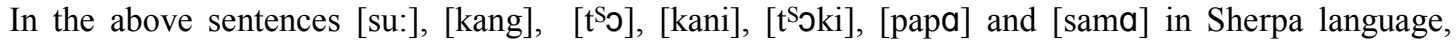

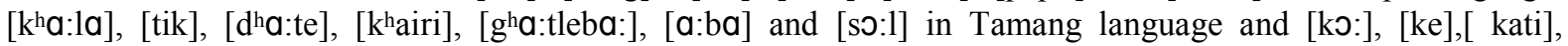
[kahă:], [katro], [bu:ba:] and [kha:na] in Nepali language refer to interrogative sentences.

\section{Optative Sentence}

The verb in the optative sentence expresses with, purpose intention, request or the tentative attitude of the speaker (Sharma, 2071: 471). The optative sentences of Sherpa language and Tamang language are listed below:

\begin{tabular}{|c|c|c|c|}
\hline Sherpa language & Tamang language & Nepali language & English language \\
\hline $\begin{array}{l}\text { [heju: hosi lunki } \\
\mathrm{k}^{\mathrm{h}} \text { undəsi] }\end{array}$ & $\begin{array}{l}\text { [torse hintsham lab: lunse } \\
\text { bo:rka:i] }\end{array}$ & $\begin{array}{c}\text { [mastiro bhaĕ hawa hurile } \\
\text { lai:za:jos] }\end{array}$ & $\begin{array}{l}\text { If it is upward, wind } \\
\text { blows. }\end{array}$ \\
\hline $\begin{array}{c}\text { [mamu həsi Kosiki } \\
\mathrm{k}^{\mathrm{h}} \mathrm{und} \text { si] }\end{array}$ & $\begin{array}{l}\text { [ma:rse hintsham gandhise } \\
\text { bo:rka:i] }\end{array}$ & $\begin{array}{c}\text { [tala tiro bhaĕ kosile } \\
\text { lai:za:ıs] }\end{array}$ & $\begin{array}{l}\text { If it is down, Koshi } \\
\text { flows. }\end{array}$ \\
\hline $\begin{array}{c}\text { [papa po:laki } \\
\text { mə:lam k }{ }^{\mathrm{h}} \text { agebu: } \\
\text { ts }{ }^{\mathrm{h}} \text { Jran senne } \\
\text { ts }{ }^{\mathrm{h}} \text { erinbu galsi] }\end{array}$ & $\begin{array}{c}\text { [a:khe a:ple mə:lamse zja:mo } \\
\text { mjo:rte] }\end{array}$ & $\begin{array}{l}\text { [buba bazekj a: sirbadle } \\
\text { hũu } \theta \text { ape zhăi aju } \theta \text { apu:n] }\end{array}$ & $\begin{array}{l}\text { Long live by the bless } \\
\text { of forefathers. }\end{array}$ \\
\hline $\begin{array}{l}\text { [dubo moulaẹ tsoran } \\
\text { tshe ripbu:galsi] }\end{array}$ & 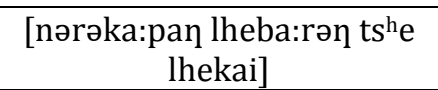 & $\begin{array}{l}\text { [dubo moulaẹ zhăi } \\
\text { moula:un] }\end{array}$ & Long live as wiregrass. \\
\hline
\end{tabular}

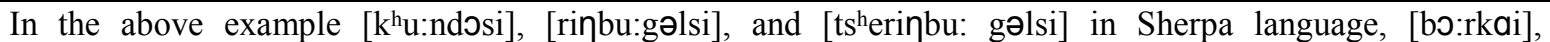
[zja:mo:mjo:rte] and [tshe lhekai] Tamang language, and [laiza:os], [aJu:Өape zhăi Өapu:n] and [dubo moula:e zhăi moula:un] in Nepali indicate optative sentences.

\section{Imperative Sentence}

Imperative sentence expresses order instruction, request, etc. by the verb (Adhikari, 2068: 218). Sherpa language and Tamang language both have the similar imperative sentences on Nepali language. Imperative sentences are in the present tense. There is only the second person subject in imperative sentence (Sharma, 2071: 490). The subject is generally omitted in imperative sentences. For example,

\begin{tabular}{|c|c|c|c|}
\hline Sherpa language & Tamang language & Nepali language & English language \\
\hline [lo:pkhan gju:k] & [lo:pkhan niu] & [skul za:u] & Go to school. \\
\hline [sama/sol so:] & [sol tshjว:jว:] & {$\left[\mathrm{k}^{\mathrm{h}} \mathrm{a}: \mathrm{na} \mathrm{k} \mathrm{h}^{\mathrm{h}} \mathrm{au}\right]$} & Eat food. \\
\hline [hor:matan/maten] & [həlla a:la:j’] & [həlla nagara] & Don't make a noise. \\
\hline [mar gju:k] & [mar niu] & [tala za:u] & Go down. \\
\hline [həer lo:] & [tor reu] & [ma: $\theta i$ utha] & Sand up. \\
\hline [dəja det] & [tsuhi dənsjaks:] & [jəha: basa] & Sit here. \\
\hline [mesila so luk/bin] & [mui ta tshe pinว:] & [v'aisilai ghas deu] & $\begin{array}{l}\text { Give grass to the } \\
\text { buffalo. }\end{array}$ \\
\hline [sa:la sjan tsว] & [gajarəri so:l dhajə:] & $\begin{array}{l}\text { [k } \mathrm{k}^{\mathrm{h}} \text { adkula:ma bha:t } \\
\text { pakau] }\end{array}$ & $\begin{array}{l}\text { Cook food in the } \\
\text { cooking pot. }\end{array}$ \\
\hline
\end{tabular}

In the above examples [gju:k], [so:], [ma:ten], [gju:k], [lo:], [det], [lu:k] and [tso:] in Sherpa language, [niu], [tshjo:jo:], [a:la:jo], [niu], [reu], [dənsjako:], [pino:] and [dhajo:] in Tamang language and [za:u], [k $\left.{ }^{\mathrm{h}} \mathrm{a}: \mathrm{u}\right]$, [nagara], [u:tha], [basa], [deu] and [paka:u] in Nepali language refer to the imperative meaning.

\section{Subjunctive Sentence}

If the verb of the sentence indicates possibility, deduction, supposition etc. the sentence is subjunctive (Sharma, 2071: 492). In Sherpa language and Tamang language the subjunctive sentences refer to future deduction or probability. All persons are used in these types of sentences. Examples are given below: 
EPRA International Journal of Environmental Economics, Commerce and Educational Management Journal DOI: 10.36713/epra0414 |ISI I.F Value: 0.815|SJIF Impact Factor (2021): 7.743

Volume: 8 | Issue: 2 | February 2021

\begin{tabular}{|c|c|c|c|}
\hline Sherpa language & Tamang language & Nepali language & English language \\
\hline 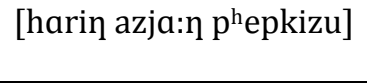 & [tini a:sjan febarbala] & [a:za ma:ma aunuhว:la] & $\begin{array}{c}\text { To maternal uncle may } \\
\text { come. }\end{array}$ \\
\hline [Pemba hembur lepzju:] & $\begin{array}{c}\text { [Pemba jamburi } \\
\text { də:tala] }\end{array}$ & $\begin{array}{c}\text { [Pemba kath mandau } \\
\text { pu:gjohว:la] }\end{array}$ & $\begin{array}{c}\text { Pemba may have } \\
\text { reached Kathmandu. }\end{array}$ \\
\hline [hatsi ts'serba gepkjuza] & [dha:re nam k $\mathrm{k}^{\mathrm{h}}$ ala:] & [bhare Pani parla:] & It may rain later. \\
\hline $\begin{array}{l}\text { [sapti sosung ha:tsi kan } \\
\text { giju] }\end{array}$ & $\begin{array}{c}\text { [tsabam tsa:zi dhare tik } \\
\text { tala hə] }\end{array}$ & $\begin{array}{l}\text { [k } \mathrm{k}^{\mathrm{h}} \mathrm{anu} \text { ta } \mathrm{k}^{\mathrm{h}} \text { ajo bhare ke } \\
\text { həla] }\end{array}$ & $\begin{array}{l}\text { He ate but what } \\
\text { happens later. }\end{array}$ \\
\hline [nup nitshezu] & [tsjo:n tsh ${ }^{\mathrm{h}}$ rtala:] & [b $\mathrm{b}^{\mathrm{h}}$ ai bjǔzhe hə:la] & $\begin{array}{c}\text { Brother may have } \\
\text { awaken. }\end{array}$ \\
\hline
\end{tabular}

In the above sentences [phepkizu], [lepzju:], [gepkjuza], [kan giju] and [nitshezu] in Sherpa language, [febarbala], [do:tala], [khala:], [tik tala ho] and [tshortala:] in Tamang language and [aunuho:la], [pu:gjoho:la], [parla:], [ke ho:la] and [bjǔzhe ho:la] in Nepali indicate subjunctive sentences.

\section{Demonstrative Sentence}

If the two clauses in a sentence have cause and effective relation, it is called demonstrative sentence (Adhikari, 2068: 220). In Sherpa language and Tamang language to show the cause and effect relation demonstrative sentences are used. Examples

\begin{tabular}{|c|c|c|c|}
\hline Sherpa language & Tamang language & Nepali language & English language \\
\hline [num tshemsi giju: $\theta$ j’] & [burin sja:sai tasela] & [bahini natse hun $\theta$ j’] & $\begin{array}{l}\text { I wish my sister to } \\
\text { dance. }\end{array}$ \\
\hline [tiwa: hju:si giju $\theta j$ ] & [Өingate $b^{\mathrm{h}}$ ra:sam tasela] & $\begin{array}{c}\text { [tiniharu hide } \\
\text { hun } \theta j \text { j] }\end{array}$ & I wish them to walk. \\
\hline [sa:ma sэ:si hugju $\theta j \jmath]$ & [sว:l tshjə:isai tasaila] & 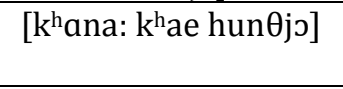 & $\begin{array}{l}\text { You'd better take } \\
\text { food. }\end{array}$ \\
\hline $\begin{array}{c}\text { [tsherba gepsi gjar ljamu } \\
\text { tsharkju: } \theta j \jmath]\end{array}$ & $\begin{array}{c}\text { [na:m k }{ }^{\mathrm{h}} \text { arsam sa:nga } \\
\text { tahasaila] }\end{array}$ & $\begin{array}{l}\text { [pa:ni pare kədə } \\
\text { maulau } \theta j \jmath]\end{array}$ & $\begin{array}{l}\text { If it rains, the millet } \\
\text { will grows. }\end{array}$ \\
\hline [ti hju:si na higu: $\theta$ e] & $\begin{array}{c}\text { [na:m bhra:mas nal } \\
\text { b }^{\text {hramaba] }}\end{array}$ & [u: hide ma hid $\theta$ e] & If he goes, will go too. \\
\hline
\end{tabular}

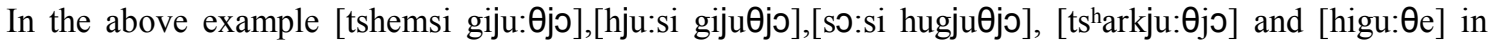
Sherpa language, [sja:sai tasela], [b ${ }^{\mathrm{h}}$ ra:sam tasela], [tshjo:isai tasaila], [tahasaila] and [ $\mathrm{b}^{\mathrm{h}}$ ramaba] in Tamang

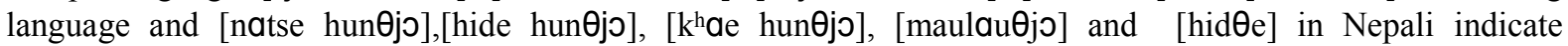
demonstrative sentence.

\section{Exclamatory Sentence}

Exclamatory sentence expresses the basic emotions like happiness, anger, hatred, surprise, pain, regret (Yadav and Regmi, 2058: 233). Unlike other sentences, exclamatory sentences may not be completed. Some of the examples of exclamatory sentences from Sherpa language and Tamang language presented here.

\begin{tabular}{|c|c|c|c|}
\hline Sherpa language & Tamang language & Nepali language & English language \\
\hline [o:hə tsə lja:mu na:zinma] & $\begin{array}{c}\text { [o:hə gha:te zja:ba } \\
\text { ts }\end{array}$ & $\begin{array}{c}\text { [o:ho kati ra:mri } \\
\text { jubati] }\end{array}$ & What a beautiful girl? \\
\hline [ninze sin] & [o:n tshja:n donzim] & [bitsara marets $\left.{ }^{\mathrm{h}} \mathrm{a}\right]$ & Alas he dead. \\
\hline 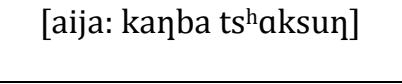 & [aija: kan kju:t tsi] & [aija: $\mathrm{k}^{\mathrm{h}} \mathrm{u}: t a:$ bhatsijग] & $\begin{array}{c}\text { Ouch! my leg is } \\
\text { broken }\end{array}$ \\
\hline [e tsila: ziwa: kju:bu:za] & [e tida: lə:nba] & [e kina daraekJ] & $\begin{array}{l}\text { Oh! why are you } \\
\text { frightened? }\end{array}$ \\
\hline [la: tshju: pesun] & [la: kjuI khjwazi] & [la: pani pə:khjo] & Eh! water dropped. \\
\hline [a: ts ${ }^{\text {hju: khja:ba: lasun] }}$ & [a: ts $\left.{ }^{\mathrm{h}} \mathrm{ju}: \mathrm{k}^{\mathrm{h}} \mathrm{a}: \eta \mathrm{tsi}\right]$ & [a: tshju za:də bhajo] & Sss! it's cold. \\
\hline
\end{tabular}

In the above examples, both Sherpa language and Tamang language have similarly in meaning in deep structure, though they differ in surface structure.

From the structural point of view there are three types of sentences in Sherpa language and Tamang language. They are simple sentence, compound sentence and complex sentence.

\section{Simple Sentence}

A simple sentence has only one clause. A simple sentence has two basic pasts as subject and predicate (Adhimkari, 2068: 268). The examples of simple sentences from Sherpa language and Tamang language are given below. 


\begin{tabular}{|c|c|c|c|}
\hline Sherpa language & Tamang language & Nepali language & English language \\
\hline [do:ma: ts $\left.{ }^{\mathrm{h}} \mathrm{emsu \eta}\right]$ & [do:ma: sja:zi] & [do:ma na:tsin] & Doma danced. \\
\hline [a:na: nusun] & [ko:ka: kra:zi] & [na:ni ro:jo:] & The baby cried. \\
\hline [tsebu:k kegesun] & [na:ka: kra:zi] & [bhale ba:sjo:] & The Cock crowed. \\
\hline [tsherwa: lesun] & [na:m k ${ }^{\mathrm{h}}$ ozi] & [pa:ni a:jə:] & Water flowed. \\
\hline [hwa:ma: ps:psun] & [nhe taizi] & [du: $\mathrm{d}^{\mathrm{h}} \mathrm{z}^{\mathrm{h}}$ arjo:] & Milk dropped. \\
\hline
\end{tabular}

In the above sentences there is only one finite verb in both Sherpa language and Tamang language.

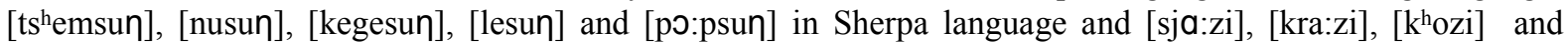
[taizi] in Tamang language are the finite verbs in simple sentences.

\section{Compound Sentence}

Compound sentences are formed by joining two or more simple sentences with equal status (Adhikari, 2068: 271). The examples of compound sentences of Sherpa language and Tamang language are given in the following table.

\begin{tabular}{|c|c|c|c|}
\hline Sherpa language & Tamang language & Nepali language & English language \\
\hline $\begin{array}{c}\text { [tigi tu:tu: me nekin tu:tu: } \\
\text { me] }\end{array}$ & 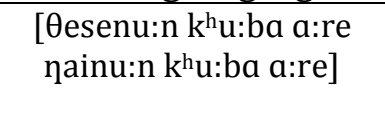 & $\begin{array}{l}\text { [u:nle pэ:ni nu:ha:eks } \\
\text { tshaina maile pə:ni } \\
\text { nu:ha:eko: tshoina] }\end{array}$ & $\begin{array}{l}\text { Neither she nor I } \\
\text { have taken both. }\end{array}$ \\
\hline $\begin{array}{c}\text { [nu:pki sama: sosun tama: } \\
\text { lэpk }^{\mathrm{h}} a: \eta \text { ga:l] }\end{array}$ & $\begin{array}{c}\text { [tsjo:n tshe ka:n tsa:zi ani } \\
\text { lopk }{ }^{\mathrm{h}} a: \eta \text { nazi] }\end{array}$ & 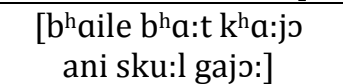 & $\begin{array}{l}\text { Brother took meal } \\
\text { and went to school. }\end{array}$ \\
\hline
\end{tabular}

In the above examples two finite verbs of Sherpa language and Tamang language are joined by similar type of conjunction as [tama:] in Sherpa language and [ani] in Tamang language.

\section{Complex Sentence}

In a complex sentence these are more than one clauses. The clauses are not in absolute relation like compound sentences rather they are in relative relation (Adhikari, 2068: 274). In Sherpa language and Tamang language complex sentences are formed by joining dependent clauses in the independent clause. For example

\begin{tabular}{|c|c|c|c|}
\hline Sherpa language & Tamang language & Nepali language & English language \\
\hline $\begin{array}{c}\text { [pemaki sa:sun gja:garla } \\
\text { zu:lus nək] }\end{array}$ & $\begin{array}{c}\text { [pemase biba: gjjgarila } \\
\text { zu:lus mu:larэ:] }\end{array}$ & $\begin{array}{l}\text { [pema:le b } \mathrm{b}^{\mathrm{h}} \text { anjs: } \\
\text { madesma: zu:lus } \\
\left.\text { rahets }{ }^{\mathrm{h}} \mathrm{a}\right]\end{array}$ & $\begin{array}{l}\text { Pemaki said that } \\
\text { there was a } \\
\text { procession in the } \\
\text { Terai. }\end{array}$ \\
\hline [na sama: sai sja:masa] & [na ka:n tsa:ba sja: atsaba] & $\begin{array}{c}\text { [ma b } \text { ba:t k}^{\mathrm{h}} \text { ants }^{\mathrm{h}} \mathrm{u} \\
\text { ma:su k }{ }^{\mathrm{h}} \text { anna] }\end{array}$ & $\begin{array}{l}\text { I eat rice but not } \\
\text { meat. }\end{array}$ \\
\hline [tak $\theta$ jne pasang nusun] & $\begin{array}{c}\text { [tsja:n mra:nsi pasang } \\
\text { kra:zi] }\end{array}$ & $\begin{array}{l}\text { [bagh dek } \text { dera pasang }^{\text {ho:jə:] }} \\
\text { roje }\end{array}$ & $\begin{array}{c}\text { Pasang cried when he } \\
\text { saw the tiger. }\end{array}$ \\
\hline
\end{tabular}

\section{CONCLUSION}

Sherpas and Tamangs both of these language fall in Tibeto-Burman family. The study is qualitative in nature. The conclusion has been drawn by collecting data with purposive interview. Both the language have similar sentence structure as subject + object + verb. While comparing sentences on meaning, declarative sentence [neki sama soi] in Sherpa language and [nai ka:n tsa:zi] in Tamang language, imperative sentence [lo:pkhan gju:k] in Sherpa language and [lo:pkhan niu] in Tamang language, interrogative sentence [su: sisung ?] in Sherpa language and [ $\mathrm{k}^{\mathrm{h}} \mathrm{a}: \mathrm{la}$ sizi ?] in Tamang language, optative sentence [heju: hosi lunki $\mathrm{k}^{\mathrm{h}} \mathrm{undosi]}$ in Sherpa and [torse hintsham lab: lunse bo:rka:i] in Tamang language, subjunctive sentence [harin azja:n $\mathrm{p}^{\mathrm{h}}$ epkizu] in Sherpa language and [tini a:sjan febarbala] in Tamang language, demonstrative sentence [num tshemsi giju:Өjo] in Sherpa language and [burin sja:sai tasela] in Tamang language and exclamatory sentence [o:ho tso lja:mu na:zinma] in Sherpa language and [o:ho gha:te zja:ba tsha:me] in Tamang language seem

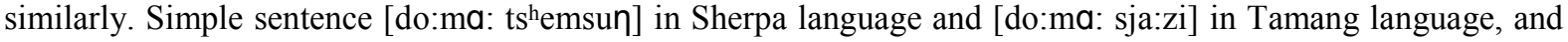
complex sentence [pemaki sa:sun gja:garla zu:lus nok] in Sherpa language and [pemase biba: gjogarila zu:lus mu:laro:] in Tamang language bear similarity. Both of these languages are agrammatical.

\section{REFERENCES}

1. Adhikari, H.R. (2065). Practical nepali grammer. Lalitpur: Sajha Publication.

2. Adhikari, H.R.(2071). Contemporary Nepali Grammer. Kathmandu: Bidyarthi Pustak Bhandar

3. Awasthi, M. and Sharma R.R.(2055). Nepali practical grammer and expression. Kathmandu: Ekra bookas and distribution Pvt. Ltd.

4. Bandhu, C. M. (2964). Sects of linguistics, 3rd Edition. Kathmandu: Ekta Books. 
5. Chaudron, C. -2009_. Second language classrooms research on teaching and learning. New Delhi : First South Asian edition.

6. Creswell, J. W. -2015_. Educational research. India : Pierson Education south Asia.

7. Crystal, D. -2003_. A dictionary of linguistics and phonetics. $5^{\text {th }}$ edition. United Kingdom : Blackwell pubishing.

8. Das, N. S. -2013_. Applied Linguistics. New Dilhi : Heritage Publishers.

9. Hocket, C. F. -2006_. Acourse in Mordern linguistics. New Delhi : Surjeet Publications.

10. Lyons, J. -1981_. Language and linguistics an introduction. United Kingdom : Cambridge University Press.

11. Neuman, W. L. -2016_. Social research methods qualitative and quantitative approaches. $2^{\text {nd }}$ edition. India : Published by Pearson India Education services Pvt.Ltd.

12. Nunan, D. -2010_. Research methods in language learning. New Delhi : Combridge University Press India Pvt.Ltd.

13. Pokhrel, M. P. (2054). Nepali sentences grammer. Kathmandu: Ekta Books.

14. Sharma, M. R. (2071). Pragya Nepali Context Grammer. Kathmandu: Nepal Prgaya Pratisthan.

15. Sherpa, D.(2058). Sherpa Bhasa Ek Adhyan. Unpublished Post Graduate Research Paper, TU.

16. Sherpa, D. (2077). Lingusitics and nepali language references. Lalitpur: Santosh sherpa lalitpur dhobighat.

17. Tamang, M. T.(2074). Contradictory study of nepali and tamang language. Tribhuwan University, Education Department, Manthali sahid smriti Multiple campus, Ramechhap.

18. Yadav, Y.P. and Regmi B. N. (2058). Lingusitics. Kirtipur: New hira books enterprises. 